\title{
The Relationship Between Defence Expenditure, Trade Openness and Foreign Direct Investments: The Case of BRICS and MINT Countries
}

\author{
Prof. Dr. Selim INANCLI, Asst. Prof. Dr. Mustafa TORUSDAG \\ 1. Sakarya University, Faculty of Political Sciences, Department of Economics, sinancli@sakarya.edu.tr, orcid \\ id: 0000-0002-7363-6216, Turkey \\ 2. Van Yüzüncü Y1l University, Department of Economics, mustafatorusdag@yyu.edu.tr, Orcid Id: 0000-0002- \\ 8839-0562, Turkey \\ * E-mail of the corresponding author: sinancli@sakarya.edu.tr
}

\begin{abstract}
This study examines the relationship among trade openness, foreign direct investments and defence expenditures for the BRICS and MINT countries in the 1990-2019 period. As analysis method, it was estimated by Pesaran (2008) Cross-Section Dependency test, Hadri-Kuruzomi (2012) panel unit root test, Pesaran (2006) CCE test and Emirmahmutoglu and Kose (2011) panel causality tests. According to the test findings, a bidirectional causality relationship was found between defense expenditures and foreign direct investments for BRICS countries. In addition, for MINT countries, there is a one-way causality relationship from defense expenditures to foreign direct investments and from trade openness to defense expenditures.
\end{abstract}

Keywords: Defence Expenditures, Trade Openness, Foreign Direct Investment, Panel Causality Analysis.

DOI: $10.7176 / \mathrm{JESD} / 13-4-01$

Publication date: February $28^{\text {th }} 2022$

\section{Introduction}

Developing countries prefer foreign resources, foreign borrowing or foreign direct investments as a source of financing while realizing their economic development goals (Cestepe et al., 2013: 2). Foreign direct investments, which are important for developing countries, create positive externalities by providing technology and knowledge transfer as well as being a source of finance. In addition, these investments can increase the integration of countries with the global economy (Angelopolou and Liargovas, 2014: 471).

It has been observed that foreign direct investments as a source of foreign financing have increased in the economic development processes of underdeveloped countries since the 1990s. Foreign direct investments are among the important actors of globalization (Yilmazer, 2010: 242, 243). As Chakrabarti (2001), trade openness is one of the determinants of foreign direct investment. According to Torissi (1985), having a trade surplus also positively affects foreign direct investments in a well-functioning economy (Uzun, 2010: 111).

The determinants factors of foreign direct investments include market volume, economic stability, trade openness, exchange rate, capital stock, infrastructure (share of public investments in the budget in energy and transportation), political risk, structural reforms, human capital (Y1lgor et al., 2011).

In the economics literature, the relationship between defence expenditures, foreign direct investments and trade openness variables with growth has been examined more. In addition, the relationship between foreign direct investments and defence expenditures, foreign direct investments and trade openness or the relationship between defence expenditures and trade openness has been studied in the literature. As a result of detailed literature review, no study has been found that handles these three variables together.

Although there have been many studies in the literature on defence spending, foreign direct investment and trade openness, the rising powers of the New World Order (NWO), BRICS (Brazil, Russia, India, China, South Africa) and MINT (Mexico, Indonesia, Nigeria and Turkey), the study is intended to contribute to the literature in terms of the limited number of studies examining this country groups.

Due to the increase in globalization and financial liberalization tendencies that led to an increase in capital movements in the world in the 1980s, the relationship between defense expenditures, foreign direct investments, trade openness for the period 1990-2019 was analyzed by the panel causality test by Emirmahmutoglu and Kose (2011). Thus, the analysis findings can be analyzed both in general and for each country.

\section{The Relationship Between Trade Openness and Foreign Direct Investment}

Trade openness is the determinant of foreign direct investment inflows. Foreign direct investments are important not only for exports but also for imports of intermediate and capital goods. In every respect, foreign direct investments increase the trade volume. Trade openness is also a determinant of foreign direct investment. Nunes et al. (2006) and Sahoo (2006), the ratio of exports and imports to GDP expresses trade openness (Vijayakumar et al., 2010: 5, 6). 
Country's trade openness is calculated by the total export and import/GDP ratio (Keskin, 2020: 19). The concept of trade openness is aimed to create an international free trade environment by removing state controls on the import and export of goods and services. It is explained as the elimination of restrictions that prevent the competitive environment by ensuring the free movement of labor and capital, as well as goods and services, between countries (Yaprakli, 2007: 68).

Trade openness is one of the effective arguments for attracting foreign direct investment to a country. While foreign direct investments prefer the country, countries' exchange rate, market volume, trade and financial openness, political stability, labor and investment costs, current account deficit, foreign debt, budget deficit, inflation, energy use level, human capital, tax rates, public expenditures. It also takes into account the macroeconomic and political stability of the countries. As Chakrabarti (2001), the degree of openness of countries to foreign trade is a determining and effective factor in foreign direct investment inflows (Karis and Ayla, 2018: $256,257)$.

Whether it prefers countries with stable foreign direct investments or whether it stabilizes the country's economies is among the controversial issues in the literature (Okuyan and Erbaykal, 2007: 48). In a country with high openness in trade, the formation of an environment of extreme competition and the hypothesis of "tariff jumping - trade restrictions" can negatively affect the economies of the countries (Keskin, 2020: 19, 20).

To investigate the relationship between trade openness and foreign direct investment, Edwards (1990), Gastanaga et al. (1998), Chakrabati (2001), Asiedu (2001), Kandiero and Chitiga (2006), Yaprakli (2006), Demirhan and Masca (2008), Snow and Sweet Words (2008), Tari and Bidirdi (2009), Jadhav (2012) ). ), Liargovas and Skandalis (2012), Cantah et al. (2013), Asghar (2016), Dima (2016), Tampakoudis et al. (2017), Terzi and Bekar (2017) concluded that there is a positive relationship between trade openness and foreign direct investment, and that trade openness is determinant in foreign direct investment inflows.

In the study of Ozcan and Arı (2010), a negative relationship was found between the two variables. Schmitz and Bieri (1972), Busse and Hefeker (2007), Vijayakumar et al. (2010), Miškinis and Juozenaite (2015), Tsaurai (2015), and Belloumi (2014) found a neutral relationship, that is, a statistically significant relationship.

\section{The Relationship Between Defence Expenditures and Foreign Direct Investments}

In the literature, the relationship of defense expenditures with growth and foreign trade has been examined, but the relationship between defense expenditures and foreign direct investment, which is seen as the driving factor of growth, has not been analyzed much (Pacific, Shan and Ramazan)., 2017: 577, 578). It is a tool in that defense expenditures are a variable related to GDP per capita and affect foreign direct investments over GDP per capita. However, defense expenditures do not directly affect foreign investment (Hussain and Kimuli, 2012: 20).

With regard to post-Cold War military spending, Drezner and Hite-Rubin (2016) state that if countries spend and invest more in their armies, foreign direct investment will lead to safer property rights and lead to more investment. Norrlof (2010) explains that military power will affect private sector investment decisions and create a safer investment environment with the concept of "Geoeconomic Nepotism". According to the geoeconomic favoritism hypothesis, it is explained that the increase in military power due to the increase in the defense expenditures of the countries will positively affect the foreign direct investments as it ensures the security of property rights (Drezner and Hite-Rubin, 2016: 2).

When a detailed literature review is made, in the studies of Kennedy (1974), Benoit (1978), Whynes (1979), Barro and Sala-i-Martin (2004), Dunne, Smith and Willenbockel (2005), defense expenditures affect the trade and economic trust environment of countries. They say it will increase economic growth by raising it.

Rothschild (1973), Smith (1980), Deger and Smith (1983), Leontief and Duchin (1983), Lim (1983), Landau (1985), Mintz and Huang (1990), Ram (1995), Dunne, Nikolaidou and In Smith (2002)'s studies, it is claimed that defense expenditures exclude productive sector investments and reduce economic growth (Aziz and Asadullah, 2017: 1; Aziz and Khalid, 2019: 240). In the studies of Acemoglu and Robinson (2012), it is argued that defense expenditures - the crowding out effect - will exclude foreign direct investments (Drezner and Hite-Rubin, 2016).

\section{The Relationship Between Trade Openness and Defence Spending}

Although there are studies on the macroeconomic determinants of defense expenditures, it is stated by Acemoglu and Yared (2010) that defense expenditures are associated with trade openness as an indicator of globalization. For this reason, the concept of trade openness is discussed in the literature mostly with the globalization dimension.

In the literature, defense expenditures are mostly examined in relation to economic growth. The relationship between globalization and defense expenditures was first reported by Dreher et al. (2006) examined and it was concluded that globalization has no effect on defense expenditures. Analysis findings of Nikolaiodu's (2008) study were also reported by Dreher et al. (2006) in the same direction.

Dunne et al. (2008) and Seiglie (2016) concluded that trade openness has a positive effect on defense spending. In Irondoust's (2007) study, it was concluded that defense expenditures increased with globalization. Solarin (2017) concluded that globalization both increased the military burden of countries and reduced their defense expenditures. 
In the study of Kurt and Kilic (2019), it was concluded that economic, political and social globalization increased defense expenditures. Acemoglu and Yared (2010) concluded that the increase in defense expenditures causes a decrease in the terms of trade of the countries. In the studies of Cengiz and Manga (2020), it was determined that political globalization increased defense expenditures, economic globalization decreased defense expenditures and social globalization had no effect on defense expenditures.

There are various opinions in the literature about the relationship between globalization and defense expenditures. In addition to the views that globalization has increased defense expenditures through social expenditures, there are also opinions that globalization has negative effects on defense expenditures and that defense expenditures should be reduced with the effect of globalization and economic liberalization. As Paul and Ripsman (2004) stated, trade and economic liberalization and the pursuit of increasing wealth force countries to use military tools. Free trade regulations also make it possible to increase defense expenditures (Solarin, 2017: $854,855)$

\section{Data and Methodology}

In this study, the causality relationship between defense expenditures, openness to trade and foreign direct investments for the period 1990-2019 and for BRICS and MINT countries is analyzed with the EmirmahmutogluKose (2011) panel causality test. The variables used in the analysis, defense expenditures and foreign direct investment data were taken from 'data.worldbank.org' database and trade openness data were taken from 'theglobaleconmy.com'. The application is made using Gauss 10 and Stata 12 econometrics programs.

Panel causality test, which is one of the second generation tests, was applied for the group of emerging market economies, BRICS and MINT countries, in terms of the relationship between defense expenditures, openness to trade and foreign direct investments. The relationship between the variables was analyzed by Pesaran (2008) Cross-Section Dependency test, Hadri-Kuruzomi (2012) panel unit root test and long-term regression coefficients of the variables Pesaran (2006) CCE (Common Correlation Effect) test and Emirmahmutoglu and Kose (2011) panel causality tests has been analyzed.

The econometric models of the study are analyzed for 3 different models as stated 1, 2 and 3 below:

$$
\text { Trade }=\mathrm{a}+\beta 1 \text { Defence }+\beta 2 \mathrm{Fdi}+\mathrm{u}
$$

$$
\text { Defence }=a+\beta 1 \text { Trade }+\beta 2 F d i+u
$$

$$
\text { FDI }=a+\beta 1 \text { Defence }+\beta 2 \text { Trade }+u
$$

In order to determine the analysis methods, firstly, the analysis of cross-section dependence and heterogeneity of the series, cointegration and causality analyzes were applied to the series after the unit root.

4.1.1. Pesaran CD (2004) Cross Section Dependency Test

With the cross-sectional dependency test, it is to examine whether the units are dependent on each other, in other words, whether a shock to a series and all cross-section units has the same effect from this shock to the series. Cross-section dependency was investigated using the Pesaran CDLM (2004) test. CDLM test statistic was derived with this cross section dependency test and this test was chosen because it can be used in cases where both $\mathrm{N}>\mathrm{T}$ and T> N. (Ozturk, 2018: 4, 5):

$C D=\sqrt{\frac{2 T}{N(N-1)}} \sum_{i=1}^{N-1} \sum_{j=i+1}^{N} T \tilde{\rho}_{i j}^{2}-1 \sim N(0,1$

The cross section dependency test is examined with CDLM test Ho zero hypothesis: $H_{0}: \rho_{i j}=\rho_{i j}=\operatorname{cor}\left(u_{i t}, u_{j t}\right)=0, i \neq \mathrm{j}$.

4.1.2. Pesaran and Yamagata (2008) Homogeneity Test

The homogeneity test for the cross sections of the slope parameters for the cointegration model was performed by Swamy (1970). Pesaran and Yamagata (2008) test N and T have different sizes and make it possible to test the homogeneity assumption. Developing two different homogeneity tests with the Swamy test, the $\beta i$ coefficients in cointegration models are analyzed with equation 2 and panel regression equation (Ozturk, 2018: 5):

$Y_{i t}=\alpha+\beta_{i} X_{i t}+\varepsilon_{i t}$

Using the equation 2 , the delta tilde value is calculated for small samples,

$\Delta=\sqrt{N}\left(\frac{N^{-1} \breve{S}-K}{\sqrt{2 K}}\right) \sim X_{k}^{2}$

Equation 4, the corrected form of the delta test statistic gives the delta tilda adj. value: 
$\triangle_{a d j}=\sqrt{N}\left(\frac{N^{-1} \breve{S}-k}{v(T, k)}\right) \sim N(0,1)$

For the delta test, Ho: slope coefficient is homogeneous and H1: slope coefficient is interpreted as not homogeneous ie heterogeneous (Pesaran and Yamagata, 2008: 56).

Table 1. Cross Section Dependency and Homogenity Tests Results

\begin{tabular}{|c|c|c|c|c|c|c|}
\hline \multicolumn{7}{|c|}{ BRICS Countries } \\
\hline Variables & \multicolumn{2}{|c|}{ Defence } & \multicolumn{2}{|c|}{ Trade } & \multicolumn{2}{|c|}{ Fdi } \\
\hline CD Tests & Stat. & Prob. & Stat. & Prob. & Stat. & Prob. \\
\hline Cd Lm2 (Pesaran 2004) & $32.350 * *$ & 0.000 & $15.081 * *$ & 0.000 & $4.547 * *$ & 0.000 \\
\hline Cd LM (Pesaran 2004 CD) & $-3.423 * *$ & 0.000 & $-3.672 * *$ & 0.000 & $-3.226 * *$ & 0.001 \\
\hline Bias-adjusted CD test & $15.212 * *$ & 0.000 & $9.996^{* *}$ & 0.000 & $1.321^{*}$ & 0.093 \\
\hline \multicolumn{7}{|c|}{ Delta Homogenity Test Results for Models } \\
\hline Homogenity Test & \multicolumn{2}{|c|}{ Model 1} & \multicolumn{2}{|c|}{ Model 2} & \multicolumn{2}{|c|}{ Model 3} \\
\hline Delta & \multicolumn{2}{|l|}{$\begin{array}{l}52.57 \\
(0.000)\end{array}$} & \multicolumn{2}{|l|}{$\begin{array}{l}39.25 \\
(0.000)\end{array}$} & \multicolumn{2}{|l|}{$\begin{array}{l}68.30 \\
(0.000)\end{array}$} \\
\hline Delta-tilda-adj & \multicolumn{2}{|l|}{$\begin{array}{l}54.49 \\
(0.000) \\
\end{array}$} & \multicolumn{2}{|l|}{$\begin{array}{l}38.96 \\
(0.000) \\
\end{array}$} & \multicolumn{2}{|l|}{$\begin{array}{l}13.35 \\
(0.000) \\
\end{array}$} \\
\hline \multicolumn{7}{|c|}{ MINT Countries } \\
\hline Variable & \multicolumn{2}{|c|}{ Defence } & \multicolumn{2}{|c|}{ Trade } & \multicolumn{2}{|c|}{ Fdi } \\
\hline CD Tests & Stat. & Prob. & Stat. & Prob. & Stat. & Prob. \\
\hline Cd Lm2 (Pesaran 2004) & $16.474 * *$ & 0.000 & $21.032 * *$ & 0.000 & $16.104 * *$ & 0.000 \\
\hline Cd LM (Pesaran 2004 CD) & $-4.189 * *$ & 0.000 & $-3.912 * *$ & 0.000 & $-4.244 * *$ & 0.000 \\
\hline Bias-adjusted CD test & $10.399 * *$ & 0.000 & $3.360 * *$ & 0.000 & $1.335^{*}$ & 0.091 \\
\hline \multicolumn{7}{|c|}{ Delta Homogenity Test Results for Models } \\
\hline Homogenity Test & \multicolumn{2}{|c|}{ Model 1} & \multicolumn{2}{|c|}{ Model 2} & \multicolumn{2}{|c|}{ Model 3} \\
\hline Delta & \multicolumn{2}{|c|}{$\begin{array}{l}9.01 \\
(0.001)\end{array}$} & \multicolumn{2}{|c|}{$\begin{array}{l}54.37 \\
(0.006)\end{array}$} & \multicolumn{2}{|c|}{$\begin{array}{l}46.02 \\
(0.001)\end{array}$} \\
\hline Delta-tilda-adj & \multicolumn{2}{|l|}{$\begin{array}{l}38.5 \\
(0.003)\end{array}$} & \multicolumn{2}{|l|}{$\begin{array}{l}10.67 \\
(0.000)\end{array}$} & \multicolumn{2}{|l|}{$\begin{array}{l}24.86 \\
(0.000)\end{array}$} \\
\hline
\end{tabular}

Note: $* * *, * * *$ indicate $10 \%, 5 \%$ and $1 \%$ significance levels, respectively Trade: Trade Openness, Defence:

Defence Expenditure, Fdi: Foreing Direct Investment.

The zero (Ho) hypothesis was rejected because the probability values were less than 0.05 of the defence expenditures, trade openness and foreign direct investment variables calculated from table 1 so it was concluded that there is a cross-sectional dependency in series. There is a cross-sectional dependency between countries belonging to each country group that constitutes the panel. In other words, the defence spending, trade openness and foreign direct investment shock coming to one of the countries affect other country groups as well.

Since the probability values of delta test statistics are less than 0.05 , the zero hypothesis is rejected. In other words, it is concluded that the constant term and slope coefficients are not homogeneous in the cointegration equation. Therefore, from the homogeneity test results, it is decided that the cointegration test interpretations of the countries in the panel are valid and reliable (Pesaran and Yamagata, 2008).

4.1.3. Hadri-Kurozumi (2012) Panel Unit Root Test

Hadri-Kurozumi (2012) panel unit root test is the adapted form of Kwiatkowski, Phillips, Schmidt and Shin (KPSS, 1992) test for panel data analysis. Unit root test was developed considering the cross-sectional dependency. This test is assumed to have a normal distribution (Temiz and Konat, 2019: 2335):

$Y_{i t}=z_{t}^{\prime} \delta_{i}+f_{t} \gamma_{i}+\varepsilon_{i t}$

Using Equation 5, the presence of the unit expressed in root panel unit root model being tested. 
Table 2. Hadri-Kurozumi (2012) Unit Root Test Result

\begin{tabular}{|c|c|c|c|c|}
\hline \multicolumn{5}{|c|}{ BRICS Countries } \\
\hline \multirow[t]{2}{*}{ Variables } & \multicolumn{2}{|c|}{$\begin{array}{c}\text { Constant } \\
\end{array}$} & \multicolumn{2}{|c|}{ Constant and Trend } \\
\hline & $\mathbf{Z}_{\mathrm{A}}^{\text {SPAC }}$ (prob) & $\mathrm{Z}_{\mathrm{A}}^{\mathrm{LA}}$ (prob) & $\mathbf{Z}_{\mathrm{A}}^{\text {SPAC }}$ (prob) & $\mathbf{Z}_{\mathrm{A}}^{\mathrm{LA}}($ prob) \\
\hline Defence & $\begin{array}{l}-1.6305 \\
(0.5015)^{* * *}\end{array}$ & $\begin{array}{l}1.6116 \\
(0.5035)^{* * *}\end{array}$ & $\begin{array}{l}0.2353 \\
(0.4070) * * *\end{array}$ & $\begin{array}{l}0.4513 \\
(0.3259) * * *\end{array}$ \\
\hline Trade & $\begin{array}{l}-1.0262 \\
(0.8476) * * *\end{array}$ & $\begin{array}{l}-1.0474 \\
(0.8525) * * *\end{array}$ & $\begin{array}{l}-1.4649 \\
(0.9285) * * *\end{array}$ & $\begin{array}{l}-1.4208 \\
(0.9223) * * *\end{array}$ \\
\hline Fdi & $\begin{array}{l}-0.4810 \\
(0.6847) * * *\end{array}$ & $\begin{array}{l}-0.3877 \\
(0.6509) * * *\end{array}$ & \begin{tabular}{|l|l|}
-0.5836 \\
$(0.7203)^{* * *}$ \\
\end{tabular} & $\begin{array}{l}-0.3324 \\
(0.6302) * * *\end{array}$ \\
\hline \multicolumn{5}{|c|}{ MINT Countries } \\
\hline & \multicolumn{2}{|c|}{ Constant } & \multicolumn{2}{|c|}{ Constant and Trend } \\
\hline Variables & $\mathbf{Z}_{\mathrm{A}}^{\text {SPAC }}$ (prob) & $\mathrm{Z}_{\mathrm{A}}^{\mathrm{LA}}($ prob) & $\mathrm{Z}_{\mathrm{A}}^{\text {SPAC }}$ (prob) & $\mathrm{Z}_{\mathrm{A}}^{\mathrm{LA}}$ (prob) \\
\hline Defence & $\begin{array}{l}13.4247 \\
(0.5775) * * *\end{array}$ & $\begin{array}{l}14.683 \\
(0.1118)^{* * *}\end{array}$ & $\begin{array}{l}39.103 \\
(0.8396)^{* * *}\end{array}$ & $\begin{array}{l}46.500 \\
(0.8793) * * *\end{array}$ \\
\hline Trade & $\begin{array}{l}0.8192 \\
(0.2063) * * *\end{array}$ & $\begin{array}{l}1.1411 \\
(0.1269)^{* * *}\end{array}$ & $\begin{array}{l}3.7938 \\
(0.7092) * * *\end{array}$ & $\begin{array}{l}4.3045 \\
(0.4087) * * *\end{array}$ \\
\hline Fdi & $\begin{array}{l}-1.0812 \\
(0.8602) * * *\end{array}$ & $\begin{array}{l}-0.8684 \\
(0.8074) * * *\end{array}$ & $\begin{array}{l}0.8306 \\
(0.2031) * * *\end{array}$ & $\begin{array}{l}1.5689 \\
(0.5083) * * *\end{array}$ \\
\hline
\end{tabular}

Note: The optimum lag lengths for the variables shown in the "L" column in the table were determined with the Schwarz information criterion. The $(* * *)$ sign in front of the test statistics obtained from the constant + trend forms indicates that the basic hypotheses for the variables are accepted at the $1 \%$ significance level. Respectively Trade: Trade Openness, Defence: Defence spending, Fdi: Foreing Direct Investment.

Hadri-Kurozumi (2012) panel unit root test for the variables of defence expenditures, trade openness and foreign direct investments of both BRICS and MINT countries, when the values with constant and constant and trend are interpreted in accordance with the analysis findings given in table 2, it is determined for both selected country groups. Since the null hypothesis cannot be rejected at the $1 \%$ significance level, it is concluded that the variables are stationary.

\subsubsection{Estimating Long Term Cointegration Coefficients}

Pesaran (2006) gives better results with the CCE estimator in small samples and analysis methods that do not consider cross-sectional dependence (Nazlığlu, 2010: 102). With the Pesaran (2006) CCE (Common Correlation Effects) estimator, the long-term cointegration coefficients of the variables are tested by considering the heterogeneity and cross-sectional dependence, and the regression coefficients are estimated for each crosssectional unit. (Keskin and Aksoy, 2019: 9). In case of $\mathrm{N}>\mathrm{T}$ and $\mathrm{T}>\mathrm{N}$, the CCE model can be used. In the CCE model, the long-term regression cointegration coefficients are estimated by two separate estimators, CCEMG (Commonly Associated Effects Average Estimator) and CCEP, given in equations 6 and 7. (Usually Associated Effects are Combined) (Pesaran, 2008: 52):

$$
\begin{aligned}
& \hat{b}_{C C E M G}=\frac{1}{N} \sum_{i=1}^{N} \hat{b}_{i} \\
& b_{C C E P}{ }^{\prime}=\left(\sum_{i=1}^{N} \theta_{i} x_{i} M_{w} x_{i}\right)^{-1}\left(\sum_{i=1}^{N} \theta_{i} x_{i} M_{w} x_{i}\right)
\end{aligned}
$$


Tablo 3. Pesaran (2006) CCE Estimation Test Result

\begin{tabular}{|c|c|c|c|}
\hline \multicolumn{4}{|c|}{ BRICS Countries } \\
\hline Models & Variables & Coef. & t-stat \\
\hline Model 1 & Defence & 1.4391 & 0.25 \\
\hline \multirow[t]{2}{*}{ Dependent Variable: Trade } & Fdi & 2.4391 & 1.47 \\
\hline & Wald chi2 $: 2.27$ & \multicolumn{2}{|c|}{ prob $>$ chi2 $: 0.322$} \\
\hline Model 2 & Trade & \begin{tabular}{l|l|} 
& -0.0038 \\
\end{tabular} & -0.45 \\
\hline \multirow{2}{*}{$\begin{array}{ll}\text { Dependent } & \text { Variable: } \\
\text { Expenditures } & \\
\end{array}$} & Fdi & -0.0436 & -1.66 \\
\hline & Wald chi2 $: 5.22$ & \multicolumn{2}{|c|}{ prob $>$ chi2 $: 0.073 * *$} \\
\hline Model3 & Defence & \begin{tabular}{l|l|} 
& -1.5563 \\
\end{tabular} & -1.54 \\
\hline \multirow[t]{2}{*}{ Dependent Varible: Fdi } & Trade & \begin{tabular}{l|l|} 
& 0.06209 \\
\end{tabular} & 2.16 \\
\hline & Wald chi2 $: 4.73$ & \multicolumn{2}{|c|}{ prob $>$ chi $2: 0.093 * *$} \\
\hline \multicolumn{4}{|c|}{ MINT Countries } \\
\hline Models & Variables & Coef. & t-stat \\
\hline Model 1 & Defence & 24.788 & 1.29 \\
\hline \multirow[t]{2}{*}{ Dependent Variable: Trade } & Fdi & -1.2652 & -0.60 \\
\hline & Wald chi2 : 3.02 & \multicolumn{2}{|c|}{ prob > chi2 $: 0.221$} \\
\hline Model 2 & Trade & 0.0014 & 0.92 \\
\hline \multirow{2}{*}{$\begin{array}{l}\text { Dependent Variable: } \\
\text { Expenditures }\end{array}$} & Fdi & \begin{tabular}{l|l} 
& 0.0720 \\
\end{tabular} & 2.44 \\
\hline & Wald chi2 : 7.48 & \multicolumn{2}{|c|}{ prob $>$ chi $2: 0.023 * *$} \\
\hline Model 3 & Defence & \begin{tabular}{l|l} 
& 1.599 \\
\end{tabular} & 1.27 \\
\hline \multirow[t]{2}{*}{ Dependent Variable: Fdi } & Trade & \begin{tabular}{|l|l|}
-0.002 \\
\end{tabular} & -0.01 \\
\hline & Wald chi $2: 1.76$ & \multicolumn{2}{|c|}{ prob $>$ chi $2: 0.414$} \\
\hline
\end{tabular}

Note: $* * *, * *, *$ indicate $10 \%, 5 \%$ and $1 \%$ significance levels, respectively Trade: Trade Openness, Defence: Defence Expenditure, Fdi: Foreing Direct Investment.

When the results expressed in table 3 are interpreted, the long-term coefficients can be interpreted since models 2 and 3 for BRICS countries and model 2 for MINT countries (probe values $<0.05$ ) are significant. According to model 2, where defence expenditures are taken as dependent variables for BRICS countries, it is concluded that a $1 \%$ increase in trade openness reduces defence expenditures by $0.0038 \%$, while a $1 \%$ increase in foreign direct investments reduces defence expenditures by $0.0436 \%$.

According to model 3, where the foreign direct investment variable is taken as the dependent variable, it is concluded that in BRICS countries, a 1\% increase in defence expenditures decreases foreign direct investments by $1.556 \%$ and a $1 \%$ increase in trade openness increases foreign direct investments by $0.062 \%$.

For MINT countries, according to model 2, where defence expenditures are taken as the dependent variable, it is concluded that a $1 \%$ increase in trade openness increases defence expenditures by $0.0014 \%$ and a $1 \%$ increase in foreign direct investments increases defence expenditures by $0.0720 \%$.

4.1.5. Emirmahmutoglu ve Kose (2011) Panel Causality Test

Since Emirmahmutoglu and Kose (2011) is a test based on the Toda-Yamamoto (1995) causality test in the panel causality test time series, the standard panel VAR estimation is first made and the appropriate lag length (p) is determined. In the next step, the integration level (dmax) of the variable with the highest integration degree is added to the $p$ lag. The level values of the series for the $(p+d m a x)$ delay are based on estimating with the panel VAR model (Sahin and Durmus, 2019: 195). It can be applied in case of cross section dependency. It is possible to analyze by using different level values of the series as $\mathrm{I}(0)$ and $\mathrm{I}(1)$. As expressed in Equations 8 and 9 , a causality analysis is applied for two variables by establishing the VAR model (Ilgaz Yildirim and Sahin, 2018: 449):

$$
\begin{aligned}
& x_{i, t}=\mu_{i}^{x}+\sum_{\substack{j=1 \\
k_{i}+\operatorname{dmax}_{i}}}^{k_{i}+\operatorname{dmax}_{i}} A_{11, i j} x_{i . t-j}+\sum_{\substack{j=1 \\
k_{i}+\max _{i}}}^{k_{i}+\max _{i}} A_{12, i j} x_{i . t-j}+\mu_{i, t}^{x} \\
& x_{i, t}=\mu_{i}^{x}+\sum_{j=1} A_{21, i j} x_{i . t-j}+\sum_{j=1} A_{22, i j} x_{i . t-j}+\mu_{i, t}^{y}
\end{aligned}
$$

$d_{\max }$ expresses the maximum degree of integration for each i. In line with the estimation results, a modified Wald (MWALD) test is applied for the $k_{i}$ delay. According to Equation 8, the $H_{0}$ hypothesis of the test is that there is a causality relationship from $\mathrm{Y}$ to $\mathrm{X}$. 
Table 4: Emirmahmutoglu ve Kose (2011) Panel Causality Direction Result

\begin{tabular}{|l|l|l|}
\hline Causality Direction & \multicolumn{1}{c|}{ Panel Fisher } & \multicolumn{1}{c|}{ P-val } \\
\hline \multicolumn{2}{|c|}{ BRICS Countries } & 0.896 \\
\hline Fdi to Trade & 4.927 & 0.981 \\
\hline Trade to Fdi & 3.004 & $0.035^{* *}$ \\
\hline Defence Expenditures to Fdi & 19.476 & $0.051^{* *}$ \\
\hline Fdi to Defence Expenditues & 18.252 & 0.788 \\
\hline Trade to Defence Expenditures & 6.314 & 0.700 \\
\hline Defence Expenditures to Trade & 7.265 & \\
\hline \multicolumn{1}{|c|}{ MINT Countries } & 0.321 \\
\hline Fdi to Trade & 9.257 & 0.966 \\
\hline Trade to Fdi & 2.407 & $0.047^{* *}$ \\
\hline Defence Expenditure to Fdi & 15.679 & 0.162 \\
\hline Fdi to Defence Expenditures & 11.761 & $0.022^{* *}$ \\
\hline Trade to Defence Expenditures & 17.909 & 0.226 \\
\hline Defence Expenditures to Trade & 10.593 & $T$ \\
\hline
\end{tabular}

Note: $* * *, * *, *$ indicate $10 \%, 5 \%$ and $1 \%$ significance levels, respectively Trade: Trade Openness, Defence: Defence Expenditures, Fdi: Foreing Direct Investment.

According to panel causality analysis in panel general findings in table 4, for BRICS countries it has been found that there is a unidirectional causality relationship between defence expenditures and foreign direct investments, while a unidirectional causality relationship from defence expenditures to foreign direct investments and from trade openness to defence expenditures in MINT countries it has been concluded.

Table 5. Emirmahmutoglu - Kose (2012) Panel Causality Test Results For Countries

\begin{tabular}{|c|c|c|c|c|c|c|}
\hline \multicolumn{4}{|c|}{ Fdi to Trade } & \multicolumn{3}{|c|}{ Trade to Fdi } \\
\hline \multicolumn{7}{|c|}{ BRICS Countries } \\
\hline $\mathrm{i}$ & Lag & Wald & p-val & Lag & Wald & $\mathrm{p}$-val \\
\hline Brazil & 1.000 & 0.005 & 0.945 & 1.000 & 0.009 & 0.925 \\
\hline Russia & 1.000 & 0.020 & 0.887 & 1.000 & 0.349 & 0.554 \\
\hline China & 1.000 & 0.186 & 0.666 & 1.000 & 0.348 & 0.555 \\
\hline India & 1.000 & 1.180 & 0.178 & 1.000 & 0.065 & 0.798 \\
\hline South Africa & 1.000 & 0.034 & 0.854 & 1.000 & 0.001 & 0.979 \\
\hline \multicolumn{4}{|l|}{ Panel Fisher : 4.927} & \multicolumn{3}{|c|}{ Panel Fisher : 3.004} \\
\hline p-value $: 0.896$ & & & & p-value & 0.981 & \\
\hline \multicolumn{7}{|c|}{ MINT Countries } \\
\hline $\mathrm{i}$ & Lag & Wald & p-val & Lag & Wald & p-val \\
\hline Mexican & 1.000 & 1.908 & 0.167 & 1.000 & 0.031 & 0.859 \\
\hline Indonesia & 1.000 & 0.030 & 0.862 & 1.000 & 0.550 & 0.458 \\
\hline Nigeria & 1.000 & 0.036 & 0.850 & 1.000 & 0.026 & 0.872 \\
\hline Turkey & 1.000 & 3.069 & $0.080 * *$ & 2.000 & 3.123 & 0.873 \\
\hline \multicolumn{4}{|l|}{ Panel Fisher : 9.257} & \multicolumn{3}{|c|}{ Panel Fisher : 2.407} \\
\hline p-value $\quad: 0.321$ & & & & p-value & 0.966 & \\
\hline
\end{tabular}

Note: $* * *, * *, *$ indicate $10 \%, 5 \%$ and $1 \%$ significance levels, respectively Trade: Trade Openness, Defence: Defence Expenditures, Fdi: Foreing Direct Investment.

In table 5, there is found that a causality relation from foreign direct investments to trade openness $(10 \%)$ for Turkey in the group of MINT countries. 
Table 6. Emirmahmutoglu - Kose (2012) Panel Causality Test Results For Countries Defence to Fdi Fdi to Defence

\begin{tabular}{|c|c|c|c|c|c|c|}
\hline \multicolumn{4}{|c|}{ Defence to Fdi } & \multicolumn{3}{|c|}{ Fdi to Defence } \\
\hline \multicolumn{7}{|c|}{ BRICS Countries } \\
\hline $\mathrm{i}$ & Lag & Wald & p-val & Lag & Wald & p-val \\
\hline Brazil & 1.000 & 17.908 & $0.001 * *$ & 4.000 & 7.590 & 0.108 \\
\hline Russia & 1.000 & 0.718 & 0.397 & 1.000 & 0.039 & 0.844 \\
\hline China & 1.000 & 0.132 & 0.716 & 1.000 & 0.430 & 0.512 \\
\hline India & 1.000 & 1.492 & 0.222 & 2.000 & 3.664 & 0.160 \\
\hline South Africa & 1.000 & 0.122 & 0.727 & 2.000 & 8.455 & $0.015 * *$ \\
\hline \multicolumn{4}{|c|}{ Panel Fisher : 19.476} & \multicolumn{3}{|c|}{ Panel Fisher : 18.252} \\
\hline \multicolumn{4}{|c|}{$\mathrm{p}$-value $: 0.035^{* *}$} & \multicolumn{3}{|c|}{ p-value $: 0.051^{* *}$} \\
\hline \multicolumn{7}{|c|}{ MINT Countries } \\
\hline $\mathrm{i}$ & Lag & Wald & p-val & Lag & Wald & p-val \\
\hline Mexican & 1.000 & 0.778 & 0.378 & 1.000 & 1.609 & 0.205 \\
\hline Indonesia & 1.000 & 6.126 & $0.013 * *$ & 1.000 & 3.073 & $0.080 * *$ \\
\hline Nigeria & 1.000 & 0.401 & 0.527 & 1.000 & 0.568 & 0.451 \\
\hline Turkey & 1.000 & 2.087 & 0.149 & 1.000 & 0.770 & 0.380 \\
\hline \multicolumn{4}{|c|}{ Panel Fisher : 15.679} & \multicolumn{3}{|c|}{ Panel Fisher : 11.761} \\
\hline \multicolumn{4}{|c|}{ p-value $\quad: 0.047 * *$} & \multicolumn{3}{|c|}{$\mathrm{p}$-value $\quad: 0.162$} \\
\hline
\end{tabular}

Note: $* * *, * *, *$ indicate $10 \%, 5 \%$ and $1 \%$ significance levels, respectively Trade: Trade Openness, Defence: Defence Expenditures, Fdi: Foreing Direct Investment.

In table 6 , it is seen that the causality relation from defence expenditures to foreign direct investments is valid for Brazil in the group of BRICS countries and Indonesia in the group of MINT countries (5\%). The causality relation from foreign direct investments to defence expenditures is valid for the BRICS countries in South Africa and for Indonesia in the MINT countries group.

Table 7. Emirmahmutoglu - Kose (2012) Panel Causality Test Results For Countries

\begin{tabular}{|c|c|c|c|c|c|c|}
\hline \multicolumn{4}{|c|}{ Trade to Defence } & \multicolumn{3}{|c|}{ Defence to Trade } \\
\hline \multicolumn{7}{|c|}{ BRICS Countries } \\
\hline $\mathrm{i}$ & Lag & Wald & p-val & Lag & Wald & p-val \\
\hline Brazil & 1.000 & 0.008 & 0.927 & 1.000 & 0.190 & 0.663 \\
\hline Russia & 1.000 & 0.144 & 0.704 & 1.000 & 0.181 & 0.671 \\
\hline China & 1.000 & 2.925 & $0.087 * * *$ & 1.000 & 1.014 & 0.314 \\
\hline India & 1.000 & 0.073 & 0.788 & 1.000 & 0.312 & 0.577 \\
\hline South Africa & 1.000 & 0.004 & 0.948 & 1.000 & 0.956 & 0.328 \\
\hline \multicolumn{4}{|c|}{ Panel Fisher $: 6.314$} & \multicolumn{3}{|c|}{ Panel Fisher : 7.265} \\
\hline \multicolumn{4}{|c|}{ p-value $\quad: 0.788$} & \multicolumn{3}{|c|}{ p-value $\quad: 0.700$} \\
\hline \multicolumn{7}{|c|}{ MINT Countries } \\
\hline $\mathrm{i}$ & Lag & Wald & p-val & $\overline{\mathrm{Lag}}$ & Wald & p-val \\
\hline Mexican & 1.000 & 3.470 & $0.063 * *$ & 1.000 & 0.862 & 0.353 \\
\hline Indonesia & 1.000 & 4.127 & $0.042 * *$ & 1.000 & 1.442 & 0.230 \\
\hline Nigeria & 1.000 & 2.691 & 0.101 & 1.000 & 1.608 & 0.205 \\
\hline Turkey & 1.000 & 0.487 & 0.485 & 1.000 & 1.067 & $0.032 * *$ \\
\hline \multicolumn{4}{|c|}{ Panel Fisher : 17.909} & \multicolumn{3}{|c|}{ Panel Fisher : 10.593} \\
\hline \multicolumn{4}{|c|}{$\mathrm{p}$-value $: 0.022^{* *}$} & \multicolumn{3}{|c|}{$\mathrm{p}$-value $: 0.226$} \\
\hline
\end{tabular}

Note: $* * *, * *, *$ indicate $10 \%, 5 \%$ and $1 \%$ significance levels, respectively Trade: Trade Openness, Defence: Defence Expenditures, Fdi: Foreing Direct Investment.

In table 7 , it is seen that the causality relation from trade openness to defence expenditures is found for China $(10 \%)$ in the group of BRICS countries and Mexico (10\%) and Indonesia (5\%) in the group of MINT countries. The causality relationship from defence expenditures to trade openness is valid only for Turkey (5\%) in the group of MINT countries.

\section{CONCLUSION}

With the collapse of the Bretton-Woods system in the late 1970s and the conversion of different currencies to convertibility, the international rate of movement of capital increased. Financial institutions, whose profit rates 
decreased in developed countries, turned to developing countries that offer higher returns through foreign direct investment in order to increase their profit rates.

This has accelerated the globalization process. The concept of globalization, which came to the fore with the changes in information, communication and technology after the 1980s, is a multidimensional concept due to its socio-economic, political and military aspects. Trade openness is an important indicator of globalization. As a result of liberalization of trade liberalization, financial liberalization and liberalization of capital movements with the effect of globalization, foreign direct investment inflows are seen as a source of technological innovation and employment as international capital movements.

In this study, the relationship between defense expenditures, foreign direct investments and trade openness for the BRICS and MINT group countries for the period 1990-2019 was examined. The analysis of the study was analyzed with Pesaran (2008) Cross-Section Dependency test, Hadri-Kuruzomi (2012) panel unit root test, and the long-term regression coefficients of the variables were determined by Pesaran (2006) CCE (Common Correlative) effect test and Emirmahmutoglu and Kose (2011) panel causality tests. has been estimated.

According to Hadri-Kurozumi (2012) panel unit root test, it was concluded that defense expenditures, trade openness and foreign direct investment variables in BRICS and MINT countries are stationary at 1\% significance level according to fixed, constant and trend values and the null hypothesis cannot be rejected. In addition, according to the unit root test findings, since the variables are not stationary at the level, it can be interpreted as the convergence of defense expenditures, trade openings and foreign direct investment for BRICS and MINT country groups.

According to the Pesaran (2006) CCE estimator for the long-term cointegration coefficient result, a $1 \%$ increase in trade openness in BRICS countries reduces defense expenditures by $0.0038 \%$, which is in line with the analysis findings of Solarin's (2017) study. It was concluded that a $1 \%$ increase in foreign direct investments decreased defense expenditures by $0.0436 \%$, a $1 \%$ increase in defense expenditures decreased foreign direct investments by $1.556 \%$, and a $1 \%$ increase in trade openness increased foreign direct investments by $0.062 \%$. It was concluded that in MINT countries, a 1\% increase in trade openness increased defense spending by $0.0014 \%$, which is consistent with the analysis findings of Dunne et al. (2008), Seiglie (2016), Irondoust (2017) and Kurt and Kilic (2019) ' results show that a 1\% increase in foreign direct investments in MINT countries increases defense expenditures by $0.0720 \%$.According to Emirmahmutoğlu - Köse (2012) panel causality analysis results, for BRICS countries, there is a bidirectional causality relationship defence expenditures and foreign direct investments. In MINT countries has been concluded that unidirectional causality relation from defence expenditures to foreign direct investments and from trade openness to defence expenditures. That is, a one way causality relationship from defence expenditures to foreign direct investments has been found for both BRICS and MINT countries.

According to the findings of causality analysis, the existence of a one-way causality relationship from defence expenditures to foreign direct investments is interpreted as that the 'Geo-Economic Nepotism' hypothesis is valid for BRICS and MINT countries and that the hypothesis is valid for Brazil (BRICS) and Indonesia (MINT) countries in particular.

When the causality analysis on the basis of countries interprets the findings for Turkey, there is a causality relationship from foreign direct investments to trade openness and defence spending to trade openness is valid. The causality relationship from foreign direct investments to defence expenditures is valid for South Africa and Indonesia. The causality relationship from trade openness to defence expenditure is valid for China, Mexico and Indonesia.

\section{REFERENCES}

Acaravci, A., \& Akyol, M. (2017), "Foreign Direct Investments, Foreign Trade and Economic Growth Relationship in Turkey", International Journal of Economics and Innovation, 3(1), 17-33.

Acemoglu, D. \& Yared, P. (2010), "Political Limits to Globalization", The American Economic Review 100, 8388.

Acemoglu, Daron, \& James A. Robinson. (2012), "Why Nations Fail: The Origins of Power, Prosperity, and Poverty", New York: Crown.

Angelopolou, Anastasia \& Liargovas, Panagiotis, (2014), "Foreign Direct Investment and Growth: EU, EMU and Transition Economies", Journal of Economic Integration, 29(3), 470-495.

Asghar, A. (2016), "Foreign Direct Investment and Trade Openness: The Case of South Asian Economies", International Journal of Innovation and Applied Studies, 17(2), 513-521.

Asiedu, E. (2001), "On the determinants of Foreign Direct Investment to Developing Countries: is Africa Different?", World Development, 30, 107-119.

Aziz, N., \& Asadullah, M., N. (2017), "Military Spending, Armed Conflict and Economic Growth in Developing Countries in the Post-Cold War Era", Journal of Economic Studies, 44(1), 47-68.

Aziz, N., \& Khalid, U. (2019), “Armed Conflict, Military Expenses and FDI Inflow to Developing Countries”, 
Defence and Peace Economics, 30(2), 238-251.

Barro, R.J. \& Sala-i-Martin, X. (2004), "Economic Growth”, 2nd ed., The MIT Press, Cambridge, MA and London.

Belloumi, M. (2014), "The Relationship Between Trade, FDI, and Economic Growth in Tunisia: An application of the Autoregressive Distributed Lag Model", Economic Systems, 38, 269-287.

Benoit, E. (1978), "Growth and Defence in LDCs." Economic Development and Cultural Change, 26, $271-280$.

Busse, Matthias \& Hefeker, Carsten (2007), "Political Risk, Institutions and Foreign Direct Investment", European Journal of Political Economy, 23, 397-415.

Cantah, W., G., Wiafe, E., A., \& Adams, A., (2013), "Foreign Direct Investment and Trade Policy Openness in Sub-Saharan Africa”, MPRA Paper, No. 58074.

Cengiz, Orhan \& Manga, Muge (2020), "Examination of the Relationship between Globalization and Defence Expenditures", Turkish Court of Accounts, 32 (117), 115-138.

Chakrabarti, A. (2001), “The Determinants of Foreign Direct Investments: Sensitivity Analyses of Cross-Country Regressions", Kyklos 54(1), 89-114.

Çeştepe, H., Yildirim, E. \& Bayar, M. (2013). Foreign Direct Investment, Economic Growth and Foreign Trade: Causality Evidence from Turkey with the Toda-Yamamoto Approach”, Akdeniz I.I.B.F. Journal, 27, 1-37.

Deger, S. \& Smith, R. (1983), "Military Expenditure and Growth in Less Developed Countries", Journal of Conflict Resolution, 27(2), 335-354.

Demirhan E, \& Masca M (2008), "Determinants of Foreign Direct Investment Flows to Developing Countries: A Cross-Sectional Analysis”, Prague Economic Paper, 4, 356-369.

Dima, S. (2016), "Globalisation, Trade Openness and Foreign Direct Investment in Romania”, Studia Universitatis Vasila Goldis Arad, 26(4), 41-53.

Dreher, A. (2006), “Does Globalization Affect Growth? Evidence from a New Index of Globalization”, Applied Economics, 38(10), 1091-1110.

Dreher, A., Sturm, J. E. \& Ursprung, H. W. (2006), "The Impact of Globalization on The Composition of Government Expenditures: Evidence From Panel Data”, CESIFO Working, Paper No. 1755, 1-40.

Drezner, D. W. \& Hite-Rubin, N., F. (2016), “Does American Military Power Attract Foreign Investment?", Sustainable Security, 51-72.

Dunne, J. P., Nikolaidou, E. \& Smith, R. (2002), "Military Spending, Investment and Economic Growth in Small Industrialising Economies", South African Journal of Economics, 70(5): $789-808$.

Dunne, J.P., Smith, R. \& Willenbockel, D. (2005), "Models of Military Expenditure and Growth: A Critical Review", Defence and Peace Economics, 16(6), 449-461.

Dunne, J., Sam, P.,F. \& Rom P.,S. (2008), "The Demand for Military Expenditure in Developing Countries: Hostility Versus Capability", Defence and Peace Economics, 19(4), 293-302.

Emirmahmutoglu, F. (2011), "Econometric analysis of money crises in developing countries, Gazi University Institute of Social Sciences", Department of Econometrics, Doctorate Thesis, Ankara.

Emirmahmutoglu, F. \& Kose, N. (2011), "Testing for granger causality in heterogeneous mixed panels", Economic Modelling, 28, 870-876.

Gastanaga, V., Nugent, J., B. \& Pashamova, B. (1998), "Host country reforms and FDI inflows: How much difference do they make?", World Development, 26 (7), 1299-1314.

Hadri, K. \& Kurozumi, E. (2012), "A Simple Panel Stationarity Test in the Presence of Serial Correlation and a Common Factor", Economics Letters, 115, 31-34.

Hussain, F., \& C.K. Kimuli. (2012), "Determinants of Foreign Direct Investment Flows to Developing Countries", SBP Research Bulletin, 8, 13-31.

Ilgaz Yildırım, Burcu \& Sahin, Dilek (2018). "Analysis of the Tourism and Energy Based Growth Hypothesis in Transition Economies: Panel Causality Test”, Igdır University Journal of Social Sciences 16, 437-457.

Irandoust, Manuchehr (2007), "Militarism and Globalization: Is There An Empirical Link?”, Quality and Quantity, $52,1349-1369$.

Jadhav, P. (2012), "Determinants of Foreign Direct Investment in BRICS Economies: Analysis of Economic, Institutional and Political Factor", Procedia-Social and Behavioral Sciences, 37, 5-14.

Kandiero, T. and Chitiga, M. (2006), "Trade Openness and FDI in Africa", South African Journal of Economic and Management Sciences, 9 (3), 355-70.

Kar, M. \& Tatlisoz, F. (2008), "Econometric Analysis of Factors Determining Direct Foreign Capital Movements in Turkey", KMU IIBF Journal, 8(14), 436-458.

Karis, Ç. \& Ayla, D. (2018), "Econometric Analysis of the Relationship between Foreign Direct Investments and Trade Openness in Turkey”, Bingöl University Social Sciences Institute Journal, 8(16), 255-271.

Kennedy, G. (1974), “The Military in Third World”, London: Duckworth.

Keskin, H., I. \& Aksoy, E. (2019), The Relationship Between Income Increase and Labor Force Participation in OECD and Developing Countries: Panel Cointegration Analysis", Third Sector Journal of Social Economy, $54(1), 1-20$. 
Keskin, S. (2020), "Foreign Direct Investments and Their Determinants: An Application on the Turkish Finance Sector”, Zonguldak Bülent Ecevit University Institute of Social Sciences Department of Economics, Master's Thesis, Zonguldak.

Kurt, U. \& Kilic, C. (2019), “The Impact of Globalization on Defence Spending: An Analysis for Turkey”, Trakya University Journal of Social Sciences, 21(1), 237-247.

Landau, Daniel (1996), "Is One of the 'Peace Dividends' Negative? Military Expenditure and Economic Growth in the Wealthy OECD Countries", Quarterly Review of Economics and Finance, 36, 183-195.

Leontief, Wassily \& Duchin, Faye (1983), "Military Spending: Facts and Figures, Worldwide Implications and Future Outlook", New York: Oxford University Press, 66.

Liargovas, P.,G. \& Skandalis, K.,S. (2012), "Foreign direct investment and trade openness: The Case of Developing Economies", Social Indicators Research, 106(2), 323-331.

Lim, D. (1983), "Another Look at Growth and Defence in Less Developed Countries”, Economic Development and Cultural Change, 31, 377-384.

Mintz, Alex and Huang, Chi (1990), "Defence Expenditures, Economic Growth, and the "Peace Dividend", American Political Science Review, 84(4): 1283-1293.

Miškinis, Algirdas \& Juozènaitè, Ilma (2015), “A Comparative Analysis of Foreign Direct Investment Factors", Ekonomika, 94(2), 7-27.

Nazlioglu, S. (2010), "The Effects of Macroeconomic Policies on the Agricultural Sector: A Comparison for Developed and Developing Countries", PhD Thesis, TC Erciyes University, Institute of Social Sciences, Kayseri.

Nikolaidou, Eftychia, (2008), "The Demand for Military Expenditure: Evidence from the EU15 (1961-2005)", Defence and Peace Economics, 19, 273-292.

Norrlof, Carla (2010), America's Global Advantage: U.S. Hegemony and International Cooperation”, Cambridge: Cambridge University Press.

Nunes, C.L., Oscategui. J. \& Peschiera. J. (2006), "Determinants of FDI in Latin America", Documento De Trabajo, 252

Okuyan, H. A., \& Erbaykal, E. (2007), “The Relationship Between Foreign Direct Investments and Economic Growth in Developing Countries", Economic Approach, 19 (67), 47-58.

Ozcan, B. and Ar1, A. (2010), "An Analysis on the Determinants of Foreign Direct Investments: The Case of the OECD”, Istanbul University Faculty of Economics Journal of Econometrics and Statistics, 12, 65-88.

Oztürk, E. (2018), "Causality Relationship Between Electricity Consumption and Economic Growth: Top MidIncome Countries Panel Data Analysis", International Journal of Business, Economics and Management Perspectives. 2(1), 1-10.

Pacific, Y., K., T., Shan, L., J., \& Ramadhan, A., A. (2017), "Military Expenditure, Export, FDI and Economic Performance in Cameroon”, Global Business Review, 18(3), 577-589.

Paul, T., V., \& N., M., Ripsman. (2004). "Under Pressure? Globalisation and the National Security State, Journal of International Studies 33(2), 355-380.

Pesaran, M.H. (2006), "Estimation and Inference in Large Heterogeneous Panels with Multifactor Error Structure", Econometrica, 74, 967-1012.

Pesaran, M. H. \& Yamagata, T. (2008), “Testing Slope Homogeneity in Large Panels”, Journal of Econometrics, $142,50-93$.

Ram, R. (1995), "Defence Expenditure and Economic Growth", In K. Hartley and T. Sandler (eds), Handbook of Defence Economics, Vol. 1. Amsterdam: Elsevier, 251-73.

Rothschild, Kurt W. (1973), "Military Expenditure, Exports and Growth”, Kyklos, 26(4), 804-814.

Sahoo, P. (2006), "Foreign Direct Investment in South Asia: Policy, Trends, Impact and Determinants", ADB Institute Discussion paper No. 56.

Schmitz, Andrew \& Bieri, Jurg (1972), "EEC Tariffs and US Direct Investments", European Economic Review, $3,259-70$

Seiglie, Carlos (2016), “Openness of the Economy, Terms of Trade, and Arms”, Southern Economic Journal, 82(3), $748-759$

Smith, R. (1980), "Military Expenditure and Investment in OECD Countries", Journal of Comparative Economics, 4(1), 19-32.

Solarin, Sakiru Adebola (2017), "Determinants of Military Expenditure and The Role of Globalisation in A CrossCountry Analysis", Defence and Peace Economics, 29(7), 853-870.

Tampakoudis, Ioannis A., Subeniotis, Demetres N., Kroustalis, Ionnis G. \& Skouloudakis, Manolis I. (2017), "Determinants of Foreign Direct Investment in Middle-Income Countries: New Middle-Income Trap Evidence", Mediterranean Journal of Social Sciences, 8(1), 58-70.

Sahin, D. \& Durmus, S. (2019), "Economic Growth in OECD Countries and Analysis of the Effects of Environmental Pollution on Health Spending”, Finance Political \& Economic Comments (647), 185-201. 
Tari, R. \& Bidirdi, H., (2009), "Main Determinants of Foreign Direct Investments in Turkey: Econometric Analysis Regarding the Period of 1990-2006", Dumlupinar University Journal of Social Sciences, 24, 253268.

Temiz, M. \& Konat, G. (2019), "Investigation of Inflation Convergence for Euro Area Countries by Panel Unit Root Test”, Business Studies Journal, 11(3), 2333-2337.

Terzi, H. \& Bekar, Akbulut Seval (2017), "The Relationship Between Foreign Direct Investments, Tourism and Openness in Turkey: The Period of 1974-2014", II. International Social Sciences Symposium, 18-20 May 2017, Alanya, 99-119.

Torissi, C., R. (1985), "The Determinants of Foreign Direct Investment In A Small LDC", Journal Of Economic Development, 10, 29-45.

Tsaurai, Kunofiwa (2015), "Trade Openness And Fdı In Zimbabwe: What Does Data Tell Us?", Corporate Ownership ve Control, 12 (4), 303-311.

Toda, H.,, Y. \& Yamamoto, T. (1995). "Statistical Inference in Vector Autoregressions with Possibly Integrated Processes", Journal of Econometrics, 66, 225-250.

Vijayakumar, N., Sridharan, P. \& Rao, K.C.S. (2010), "Determinants of FDI in BRICS Countries: A Panel Analysis", International Journal of Business Science and Applied Management, 5 (3), 1-13.

Whynes, D., K. (1979). "The Economics of Third World Military Expenditure", London: Macmillan.

Yaprakli, S. (2007), "The Relationship Between Trade and Financial Openness and Economic Growth: An Application on Turkey", Istanbul University, Faculty of Economics, Journal of Econometrics and Statistics, Issue: 5 .

Yılgor, M., Serel, A. \& Erçakar, M., E. (2011), "Factors Affecting the Arrival of Foreign Direct Investments: A Model on Turkey", Balıkesir University Journal of Social Sciences Institute, 14 (26), 119-131.

Yilmazer, M. (2010), "The Relationship Between Foreign Direct Investments, Foreign Trade and Economic Growth: An Essay on Turkey", Celal Bayar University Social Science Institute Journal, 8 (1).

Yurttancikmaz, Z., C.. (2014), "Determinants of Competitiveness and Growth Relations in Selected Countries", Erzurum Atatürk University Institute of Social Sciences, Department of Economics, Doctorate Thesis, Erzurum. 